\title{
Do racionalismo à ética da alteridade: contribuições de Paul Tillich e Ricoeur para a compreensão das imagens do Deus da Revelação
}

\author{
Orientador: Joel Portella Amado \\ Doutoranda: Silvana Gomes Venancio \\ Área de Concentração: Teologia Sistemático-Pastoral \\ Linha de Pesquisa: Religião e Modernidade
}

A proposta desta tese foi afirmar que nos primeiros séculos da teologia cristã, a união com a filosofia grega foi um dos motivos do afastamento da alteridade, gerando uma imagem de Deus. Desse encontro, nasce uma teologia excessivamente preocupada com a verdade, sendo todos os que pensam diferente são afastados e condenados como hereges. Não existindo espaço para o dialogo, para a divergência, para a pluralidade, sendo assim, o principio da comunhão é substituído pelo conhecimento. Outro desenvolvimento importante nesta tese foi ampliar as maneiras de falar de Deus que não fossem apenas a do instrumental filosófico, no intuito de gerar novas imagens de Deus. Uma dessas maneiras foi a virada hermenêutica, cuja proposta é deixar de lado uma interpretação única, tendo como parâmetro a vida no mundo contemporâneo. Outro caminho realizado na pesquisa foi a tentativa de fugir de um racionalismo estéril que reduzia o conhecimento de Deus a uma dimensão intelectual. Como alternativa, a pesquisa sugeriu que o conhecimento de Deus fosse acompanhado de um comportamento ético, que incluísse o mistério, a vida, a justiça, e o amor. Tudo isso, no sentido, de dar uma fundamentação teológica que levasse em direção ao outro, buscando assim, uma ética da alteridade e do reconhecimento mútuo. A pesquisa teve como um dos objetivos buscar uma reflexão teológica que respondesse por que o cristianismo foi e continua sendo tão intolerante com as diferenças. Esse percurso foi realizado com as contribuições de Paul Tillih, Paul Ricoeur e outros autores.

Palavras-chave: Alteridade. Filosofia Grega. Verdade. 